\title{
A COMPARATIVE ANALAYSIS OF INTER-SITE GENE EXPRESSION HETEROGENICITY OF NORMAL HUMAN BUCCAL MUCOSA WITH NORMAL GINGIVAL MUCOSA
}

\section{AUTHORS}

\section{Dr. Thavarajah Rooban}

Corresponding Author

Professor, Department of Oral Pathology, Ragas Dental college and Hospital, Affiliated to the Tamil Nadu Dr. MGR Medical University, 2/102 East Coast Road, Uthandi, Chennai, 600119, India

E-mail - t.roobanmds@gmail.com;

+91-9551096200

\section{Dr. Kannan Ranganathan}

Professor and Head, Department of Oral Pathology, Ragas Dental college and Hospital, Affiliated to the Tamil Nadu Dr. MGR Medical University, 2/102 East Coast Road, Uthandi, Chennai, 600119 


\section{A COMPARATIVE ANALAYSIS OF INTER-SITE GENE EXPRESSION HETEROGENICITY OF NORMAL HUMAN BUCCAL MUCOSA WITH NORMAL GINGIVAL MUCOSA}

\section{ABSTRACT}

BACKGROUND: Description of heterogeneity of gene expression of various human intraoral sites are not adequate. The aim of this study was to explore the difference of gene expression profiles of whole tissue obtained from apparently normal human gingiva and buccal mucosa (HGM, HBM). MATERIALS AND METHODS: Gene sets fulfilling inclusion and exclusion criteria of HGM and HBM in gene Expression Omnibus(GEO) database were identified, segregated, filtered and analysed using the ExAtlas online web tool using pre-determined cut-off. The differentially expressed genes were studied for epithelial keratinization related, housekeeping(HKG), extracellular matrix related(ECMRG) and epithelial-mesenchymal transition related genes(EMTRGs). RESULTS: In all 40 HBM and 64 HGM formed the study group. In all there were 18012 significantly expressed genes. Of this, 1814 were over-expressed and 1862 under-expressed HBM genes as compared to HGM. One in five of all studied genes significantly differed between HBM and HGM. For the keratinization genes, 1 in 6 differed. One of every 5 HKG-proteomics genes differed between HBM and HGM, while this ratio was 1-in 4 for all ECMRGs and EMTRGs. DISCUSSION: This difference in the gene expression between the HBM and HGM could possibly influence a multitude of biological pathways. This result could explain partly the difference in clinicopathological features of oral lesions occurring in HBM and HGM. The innate genotypic difference between the two intra-oral niches could serve as confounding factor in genotypic studies. Hence studies that compare the HBM and HGM should factor-in these findings while evaluating their results. 
KEYWORDS: Gene expression; Control tissues; Buccal mucosa; Gingiva; Normal oral mucosa

\section{BACKGROUND}

Gene expression serves as a bridge between information encoded within a gene and the final functional gene product, such as a protein or non-coding RNA. The orchestrated process of gene expression can be altered at any stage to modify the quantity and spatiotemporal parameters of the functional protein appearance. This is essential for preserving normal cellular structure and function. The cellular capacity to control gene expression permits it to supply a functional protein whenever it is required for its normal survival or function. This system is involved in a variety of physiological and pathological processes, including cellular adaptation to new surroundings, homeostasis maintenance, and damage recovery. ${ }^{[1]}$ Gene expression widely differs between the various tissues and site. It follows "tissue-specific" or signature expression patterns, reflecting possibly the differences in metabolic activity and cyto-architecture. ${ }^{[2]}$ Generally, all human cells contain identical housekeeping genes (the genes in every tissue; maintains cellular functions).

Fibroblasts from different parts of the human body exhibit heterogeneity with respect to cell behaviour, proliferative potential, response to growth factors and matrix biosynthesis. They also exhibit functional specialization according to the tissue of origin, site, and spatial location, even in the same tissues. Intra-site and inter-site heterogeneity of fibroblasts have been characterized in tissues like gingiva, periodontal ligament, and forearm skin. They often differ in their proliferative potential, ability to form colonies in semi-solid medium, cellular response to cytokines, secretion of matrix-degrading enzymes, migratory behaviour, cytokine production and matrix deposition. ${ }^{[3]}$ 
Fibroblast of anatomically distinct sites have distinct transcriptional patterns. On appropriate stimulation, the relatively quiescent fibroblasts can acquire an active synthetic, contractile phenotype and express several smooth muscle cell markers, which are not exclusive for fibroblasts of that particular niche. ${ }^{[4,5]}$ Failure to account and consider the phenotypic as well as expression profile of these heterogenic differences can lead to potential erroneous interpretation of data collected for the specific experimental purposes. ${ }^{[6]}$ All oral fibroblasts are derived from the ecto-mesenchymal cells of the cranially migrated neural crest cells. In spite of the same lineage, there is anatomical, histological heterogeneity among various intra-oral sites. ${ }^{[7]}$

Human buccal fibroblasts (HBF) have partly primed, committed cells of neural crest lineage characterised by plasticity and longevity controlled by WNT and p53 gene network. ${ }^{[8]}$ The existence of heterogeneity in human gingival fibroblasts (HGF) is documented, particularly those of the gingival papillary and reticular area ${ }^{[9,10]}$ A subset population of HGF is known to heal without fibrosis. ${ }^{[1]}$ When HGF and HBF cultured fibroblasts were studied, the cell density migration index was higher in HBF than HGF. On the other hand, the HGF had more adult phenotype in contrast to foetal phenotype of HBF. ${ }^{[9]}$

Oral epithelial cells are exposed to external environment and they also interact extensively with underlying cells such as fibroblasts and immune cells. Alteration in fibroblasts influences proliferation, repair and inflammatory cytokine secretion and factors released by fibroblasts influence overlying epithelial cells. ${ }^{[12]}$ Oral keratinocytes interact with themselves and underlying connective tissue to provide a tight barrier and heal when damaged. $^{[13-16]}$

The aim of this manuscript was to study the difference of expression profiles of epithelial and the extracellular matrix (ECM) components of whole tissue obtained from two common 
oral niches - gingiva and buccal mucosa from publicly available Gene Expression Omnibus GEO datasets.

\section{MATERIALS AND METHODS}

\subsection{Source of microarray datasets}

A systematic search of the National Centre for Biotechnology Information (NCBIGEO - http://www.ncbi.nlm.nih.gov/geo) repository using the keywords "buccal mucosa" "gingiva" was carried out. The microarray datasets and their descriptions contents were further limited to a. in Humans - Homo sapiens b. type - "expression profiling by the array.", c. has normal healthy patient, tissue biopsy (epithelium and connective tissue) sample with no obvious disease d. ideal, acceptable extraction protocol e. has mRNA. Datasets that were from culture explants or had only fibroblasts or only keratinocytes or non-tissues or that unclear extraction protocols or sources or details were excluded. No emphasis was placed on types of dataset platforms. The gene series were collated.

\subsection{Pair-Wise Comparison}

The individual patient's gene expression datasets from methodically reviewing and screening the microarray datasets were collated using the pair wise comparison using the ExAtlas online web tool at https://lgsun.irp.nia.nih.gov/exatlas. ${ }^{[17]}$ The genes from the GEO datasets were $\log _{2}$ transformed, normalized with quantile normalization method and later combined. Then, the samples - Human Buccal Mucosa (HBM) and Human Gingival Mucosa (HGM) gene-sets were combined. Principal component analysis was performed to check the tissue/gene distribution with FDR $\leq 0.05$, correlation threshold $=0.7$ and fold change threshold of 2. In the tool, PCA is calculated using the Singular Value Decomposition (SVD) method that generates eigenvectors for rows as well as columns of the log-transformed data 
matrix. ${ }^{[17]}$ For plotting of tissues and genes (biplot) column projections were used as biplots is helpful for visually exploring associations between genes and tissues.

A pairwise compared with ANOVA statistical methodology was employed to compare HBM and HGM. The quality assessment measurement of the samples within the pooled datasets was the standard deviation $(\mathrm{SD})$ value, and the criterion was $\mathrm{SD} \leq 0.3$. The correlation of gene expression for housekeeping genes was established at $>0.5$. The false discovery rate (FDR) based on the Benjamini-Hochberg was $\leq 0.05$ and fold change was fixed at 2 . The scatter plot was made to identify the over-expressed and under-expressed genes in HBM as compared to HGF. Only genes that had gene symbol was considered for further studies.

\subsection{Gene-set enrichment analysis of up/down-regulated genes}

The listed genes were then used to compare with the Public human Gene Ontology gene set with functional role of 9606 genes. ${ }^{[18,19]}$ A FDR $\leq 0.05$, fold enrichment threshold of 2 and a minimum of 5 gene overlap in biological process was kept as standard norms. For this purpose, exatlas tool employs, Parametric Analysis of Gene Enrichment (PAGE) as it is simple and reliable. ${ }^{[20,21]}$

\subsection{Differential expression of epithelial keratinization related genes}

The genes associated with epithelial keratinization were collected from gene ontology (GO: 0031424; http://amigo.geneontology.org/amigo/term/GO:0031424). The differentially expressed genes from section-2.2 were assessed for the same.

\subsection{Differential expression of housekeeping gene}


From a database of human housekeeping genes (HKG-proteomics) (https://www.proteinatlas.org/humanproteome/tissue/housekeeping), the results of section-2.2 were compared and the housekeeping genes that were differentially expressed between HBM and HGM tabulated. ${ }^{[22]}$

\subsection{Differential expression of extracellular matrix related genes [ECMRGs]}

The list of over and under-expressed genes of HBM as compared to HGM was searched for extracellular matrix (ECM) and annotated according to matrisome divisions (core matrisome or matrisome-associated) and categories (ECM glycoproteins, collagens and proteoglycans, for core matrisome genes, ECM-affiliated, ECM regulators and secreted factors, for matrisome-associated genes) in lines as proposed by Naba et al., using the MatrisomeAnnotator tool at http://matrisomeproject.mit.edu/analytical-tools/matrisome$\underline{\text { annotator/ }}^{[23]}$

\subsection{Differential expression of epithelial-mesenchymal transition related genes [EMTRGs]}

From the database of human epithelial-mesenchymal transition (EMT) database, the results from section-2.2 were compared and the differentially expressed EMT genes were listed out. ${ }^{[24]}$

\subsection{Differential expression of fibroblast markers}

The list of fibroblast markers of heterogeneity as revealed by recent single-cell analysis through cell identification and discrimination was collected from previously published literature. ${ }^{[25]}$ A comparison of the same was performed based on ANOVA results and the overlap tabulated along with rank.

\section{RESULTS}




\subsection{Microarray datasets}

From the publicly available database, in early March 2021, a total of 4 datasets (GSE7307, $\mathrm{n}=4$; GSE3526, $\mathrm{n}=4$; GSE17913, $\mathrm{n}=40$ ) non-smoker HBM and 5 datasets (GSE106090, n=6; GSE10334, n=64; GSE4250, n=2; GSE3374, n=8; GSE23586, n=3) had healthy HGM were collected and processed in the Exatlas software as outlined. In all there were $48 \mathrm{HBM}$ and $83 \mathrm{HGM}$ gene-sets. All these gene-sets were subjected to quality assessment procedure as previously outlined. Those sets whose house keeping genes did not fulfil the required minimum quality parameters of correlation or SD were removed from further analysis. After removal of non-qualifying datasets, a total of $40 \mathrm{HBM}$ and $64 \mathrm{HGM}$ formed the final study group. The final study group gene-set had used GPL570 platform to analyse the array.

\subsection{Pair-wise comparison}

The final combined dataset had 104 samples comprising 22738 probes. Of this, 22139 had gene symbol. Of this there were 18012 genes with FDR $\leq 0.05$ and included in the PCA. The relationship of tissues and genes are shown in figure-1A, 1B. Of the PCA, the component 1 had an Eigen value of 27.17 accounting for $90.16 \%$ of all genes (Figure-2). The scatter-plot was obtained (Figure-3) with HBM showing 1843 (1814 with gene symbols) overexpressed genes and 1915 (1862 with gene symbols) under-expressed genes as compared to HGM. In all, of the 18012 genes, 3758(20.86\%) were differentially expressed with statistical significance.

\subsection{Gene-set enrichment analysis of up/down-regulated genes}

The over/under expressed gene enrichment analysis using Gene-Ontology is shown in supplementary file-1, (Tables1, 2). There were 217 biological processes in over-expressed 
genes. The commonly involved GO processes (>15\% of cluster) and their cluster frequency included anatomical structure development (GO:0048856, 37.14\%), biosynthetic process(GO:0009058, 33.64\%), cellular nitrogen compound metabolic process(GO:0034641, 31.34\%), signal transduction(GO:0007165, 30.62\%), transport(GO:0006810, 28.2\%), cell differentiation(GO:0030154, 26.39\%), cellular protein modification process(GO:0006464, 21.86\%), response to stress(GO:0006950, 21.86\%), cellular component assembly(GO:0022607, 17.69\%) and catabolic process (GO:0009056, 16.3\%).

The under-expressed genes were associated with 192 biological processes. Of the under-expressed processes in HBM, the most common include ECM, CXCR chemokine, hemidesmosomes, collagen-activated tyrosine kinase receptor signalling pathway as compared to HGM. (Supplemental file-1, tables-3,4) Of the under-expressed genes, the commonly involved GO processes (>15\% of cluster) and their cluster frequency included cellular nitrogen compound metabolic process (GO:0034641; 36.81\%), anatomical structure development (GO:0048856; 35.17\%), biosynthetic process (GO:0009058; 34.58\%), signal transduction (GO:0007165; 34.23\%), transport (GO:0006810; 32.24\%), cellular protein modification process (GO:0006464; 25.73\%), cell differentiation (GO:0030154; 25.5\%), response to stress (GO:0006950; 24.97\%), immune system process (GO:0002376; 20.75\%), catabolic process (GO:0009056; 19.17\%), cellular component assembly (GO:0022607; $17.53 \%)$ and cell death (GO:0008219; 15.01\%).

\subsection{Differential expression of epithelial keratinization related genes}

In all there were 227 genes associated with epithelial keratinization. Of this, there were 13 genes overexpressed and 25 under-expressed in HBM as compared to HGM. Combined, this 38 genes accounted to $16.74 \%$ of all keratinization associated genes. 
Of the 13 genes overexpressed in HBM, 5 were keratin related (KRT31, KRT33A, KRT33B, KRT7, KRT78). The other genes are FLG, KLK5, KRTAP3-2, PPL, PRSS8, SPINK5, ST14 and TGM1. Of the 25 under-expressed genes, 7 were keratin related (KRT2, KRT3, KRT4, KRT10, KRT16, KRT24, KRT76). The rest includes ABCA12, CAPN1, CDH3, CDSN, CYP26B1, DSC1, JUP, KAZN, LCE1B, LCE1E, LCE2B, LCE3D, LORICRIN, PCSK6, PI3, PKP2, RPTN and SPRR2G.

\subsection{Differential expression of housekeeping gene}

There were 9638 genes identified in the HKG-Proteomics database. Of this, 1910 (19.38\%) of all HKG-Proteomics) were identified in the differentially expressed genes of this study. This 1910 contributed to $52 \%$ of all differentially expressed genes in this study. Of the 1910 genes, 824 (43.14\%) were over-expressed and 1086 (56.86\%) were under-expressed.

\subsection{Differential expression of ECMRGs}

There are 847 ECMRGs identified and reported. ${ }^{[26]}$ The identified over/underexpressed genes were subjected to matrisome analysis. Of the 1843 genes over-expressed in HBM as compared to HGM, there were 99 matrisome related factors (core matrisome (2 collagens - Col6A6; Col10A1; 29 ECM Glycoproteins and 4 proteoglycans), matrisome associated (24 ECM regulators, 15 ECM affiliated proteins, 25 secreted factors) (Table-1). Of the 1915 genes under-expressed in HBM as compared to HGM, there were 102 matrisome related factors (core matrisome (12 collagens; 16 ECM Glycoproteins and 2 proteoglycans), matrisome associated (37 ECM regulators, 5 ECM affiliated proteins, 30 secreted factors). (Table-2) In all, 201 ECMRGs of the 847 were differentially expressed in the present study. This accounts to $23.73 \%$ of the ECM genes.

\subsection{Differential expression of EMTRGs}


There were 1184 human EMTRGs. Of the 1843 overexpressed HBM genes, 134(7.3\%) were EMT genes and 1915 under-expressed genes, $156(8.1 \%)$ were EMT genes. This difference was not statistically significant. $(\mathrm{P}=0.173)$ The differentially expressed 290 EMT related genes in present study accounted to $24.49 \%$ of all known EMT genes.

\subsection{Differential expression of fibroblast markers}

Of the 45 listed markers, there were 37 distinct markers differentially expressed between HBM and HGM. Of the 37 markers, 22 genes (PCOLCE2, MFAP5, LUM, ABCA8, DPT, CELF2, SCARA5, IGFBP6, MFAP4, LPAR1, GSN, C3, RNASE4, MEDAG, FBLN1, PI16, CD34, LSP1, S100A16, HTRA3, CCDC80, OLFML3) were over-expressed in HBM while 15 genes (PDGFRA, BICC1, DPEP1, SLC43A3, HEG1, LOXL1, FBLN2, COL1A2, MMP2, COL5A1, COL1A1, HSD11B1, DCN, AV1, ADAMTS2) were under-expressed in HBM as compared to HGM. The extent of difference is listed in as table-3 with rank and desired statistics.

\subsection{Overall difference between gene expression of HBM and HGM}

Among all the significant genes in this study, 1-in-5 significantly differed between HBM and HGM. For the keratinization genes, 1 in 6 differed. One of every 5 HKGproteomics genes differed between $\mathrm{HBM}$ and $\mathrm{HGM}$, while this ratio was 1 -in 4 for all ECMRGs and EMTRGs. (Figure-XX)

\section{DISCUSSION}

Several studies have reported the spatio-temporal gene expression difference among various human tissues, organs and even different parts of same organ, including skin, adipose tissue, brain, cornea and epidymis. ${ }^{[27-32]}$ The role of heterogeneity of gene expression of 
fibroblasts of various sites and its implication on human diseases have been reported. ${ }^{[33]}$ Studies exploring the heterogeneity of the various intra-oral sites in terms of $\mathrm{pH}$, histo-cytoarchitecture, immune-topology and gene expressions are limited. ${ }^{[7-16,34,35]}$ Existing studies have reflected the inherent differences between the various intra-oral sites and even among the same site such as gingiva and periodontium. ${ }^{[9,10,11]}$ The spatio-temporal heterogeneity of the gingiva at single cell level has been recently described widening our understanding of the biology of these intra-oral sites. ${ }^{[36]}$ The intra-oral site specific gene expression differences in pathologic process also has been previously reported. ${ }^{[36,37]}$ However, the innate difference between the gene expression of whole HBM and HGM among normal, non-diseased population has not been reported. Hence this study was attempted.

The present study reveals the existence of substantial difference between the HBM and HGM in terms of gene expression. The figure-xx shows the extent of difference. The difference emanates from the basic housekeeping genes, keratinization process to complex ECMRGs and EMTRGs. This inherent difference in gene expression may have ramification and may partially account for site predilection of pathologies. ${ }^{[37,38]}$ In addition to differential expression, the net difference in key biological reactions between HBM and HGM have been evidenced by change in the KEGG pathways. The alterations could be reflecting on the molecular profile of the cells of HBM and HGM.

For a typical biomedical research involving molecular techniques, the need for positive and negative control is mandatory. There are guidelines for the use of such procedure related control tissues and mandatory reporting format. ${ }^{[39]}$ However, to the best of our knowledge, there are only few suggestions and deliberations for "normal" tissues that are involved as an experimental control arm, especially in oncology. ${ }^{[40]}$ Ethically, ideal normal tissues are difficult to acquire. ${ }^{[41-43]}$ Most of the bioethical guidelines in force advises against incising/excising or enlarging to non-lesional areas, for the exclusive purpose of conducting a 
research. ${ }^{[42]}$ Generally a normal tissue that is trimmed/excised for approximation after unrelated surgical treatment, after voluntary consent is used as normal tissues. ${ }^{[43]}$ This "uninvolved matching" tissue may not a true representation of a native, normal tissue because molecular changes may have occurred under the influence of adjacent infection, inflammation or an adjacent neoplastic process ("condemned mucosa"). When "normal" tissue is required as a control arm, it becomes pertinent to specify what tissues constitute "normal" and justify that such a tissue (if from diseased entity) would not have altered molecular signals that could adversely influence the outcome of the comparison. ${ }^{[41]}$ The influence of age, gender and habits need to be also accounted. The apparent clinically normal tissues could possibly harbour mutations and molecular changes that could potentially influence the outcome of comparisons. ${ }^{[40]}$ Hence the apparent healthy tissues should be used with caution.

Some investigators request normal tissues from trauma cases or edges of chronic infection and even from preserved anatomic entities. Wound approximation edges from trauma cases may be contaminated and if late, be affected by inflammatory process. Similarly chronic inflammation could alter the molecular nature of the native tissues. It may not be ethical to obtain tissues from autopsies or stored specimen because these may be done without consent. $^{[41]}$

There has been attempts to elucidate the normal human differential protein expression in various tissues. Even in the study, different intra-oral sites have not been evaluated in such attempts except for tongue. ${ }^{[44,45]}$ Cancer process per se, are known to down-regulate tissue specific genes and are directly associated with prognosis. While studying differences between same type of cancer (for example oral squamous cell carcinoma) at different sites (of oral cavity), the inherent difference between the normal tissues would be highlighted more rather 
than differences between those that are independent of normal tissue physiology. ${ }^{[46]}$ If not accounted, this phenomenon may lead to erroneous conclusions.

In studies involving human oral diseases, the normal, non-diseased control tissues are often obtained from gingival tissues or from the retromolar tissue- an area where HBM and HGM meet. In such instance, with chronic exposure to pro-inflammatory and pro-fibrotic cytokines, as in inflammation, the connective tissue and epithelium may be irreversibly damaged. As a part of reparative mechanism, there could a cascade of triggered epigenetic modifications and activation of related genes, leading to their engagement in further differentiation and fibrosis development. Based on the type of cells, the reaction could also widely vary. There are gaps in knowledge regarding this complex mechanism at the cellular and molecular levels. ${ }^{[47]}$ The biological niches in the HBM and HGM are different. In addition, the normal tissue resident microbial flora could influence the gene expression. There are recent reports emanating from cancer and normal tissues. ${ }^{[48,49]}$ In such a background, the inherent geno-typological difference between HBM and HGM, as evidenced in this study assumes an important role.

Limitation of the study includes using samples from different studies and population, though the difference have been accounted for in the analysis; the samples differing from several studies but had used one platform; stringent quality control parameter being enforced; non-consideration of age, gender, and deleterious habits. Future studies need to account for the same.

\section{CONCLUSION}

An attempt is made to characterize the genetic expression of HGM and HBM using pre-existing dataset and employing stringent statistical approach. The study identified that 1in-5 genes significantly differed between HBM and HGM. Of genes responsible for 
keratinization process, 1 in 6 differed. Similarly housekeeping genes, genes associated with extracellular matrix and epithelial-mesenchymal transition were also significantly altered. This inherent genotypic difference between the 2 intra-oral niches could mislead the genotypic studies, if the differences are not properly accounted. Future studies that compare the HBM and HGM should factor-in the findings while evaluating their results. Large scale prospective studies are needed further to validate the findings.

\section{REFERENCES}

1. Volgin DV. Gene Expression: Analysis and Quantitation. In Animal Biotechnology Edited by Verma AS, Singh A. 2014 Jan 1 (pp. 307-325). Academic Press, Elsevier, Oxford, UK

2. Hsiao LL, Dangond F, Yoshida T, Hong R, Jensen RV, Misra J, Dillon W, Lee KF, Clark KE, Haverty P, Weng Z, Mutter GL, Frosch MP, MacDonald ME, Milford EL, Crum CP, Bueno R, Pratt RE, Mahadevappa M, Warrington JA, Stephanopoulos G, Stephanopoulos G, Gullans SR. A compendium of gene expression in normal human tissues. Physiol Genomics. 2001 Dec 21;7(2):97-104. doi: 10.1152/physiolgenomics.00040.2001. PMID: 11773596

3. Irwin CR, Picardo M, Ellis I, Sloan P, Grey A, McGurk M, Schor SL. Inter- and intra-site heterogeneity in the expression of fetal-like phenotypic characteristics by gingival fibroblasts: potential significance for wound healing. J Cell Sci. 1994 May;107 ( Pt 5):1333-46. PMID: 7929639.

4. Chang Y, Li H, Guo Z. Mesenchymal stem cell-like properties in fibroblasts. Cell Physiol Biochem. 2014;34(3):703-14. doi: 10.1159/000363035. Epub 2014 Aug 18. PMID: 25171291. 
5. Muhl L, Genové G, Leptidis S, Liu J, He L, Mocci G, Sun Y, Gustafsson S, Buyandelger B, Chivukula IV, Segerstolpe Å, Raschperger E, Hansson EM, Björkegren JLM, Peng XR, Vanlandewijck M, Lendahl U, Betsholtz C. Single-cell analysis uncovers fibroblast heterogeneity and criteria for fibroblast and mural cell identification and discrimination. Nat Commun. 2020 Aug 7;11(1):3953. doi: 10.1038/s41467-020-17740-1. Erratum in: Nat Commun. 2020 Sep 3;11(1):4493. PMID: 32769974; PMCID: PMC7414220.

6. Thompson RG, Nickel B, Finlayson S, Meuser R, Hamerton JL, Wrogemann K. 56K fibroblast protein not specific for Duchenne muscular dystrophy but for skin biopsy site. Nature. 1983 Aug 25-31;304(5928):740-1. doi: 10.1038/304740a0. PMID: 6888542.

7. Ciano J, Beatty BL. Regional quantitative histological variations in human oral mucosa. Anat Rec (Hoboken). 2015 Mar;298(3):562-78. doi: 10.1002/ar.23097. Epub 2015 Feb 2. PMID: 25402000.

8. Miyoshi K, Horiguchi T, Tanimura A, Hagita H, Noma T. Gene Signature of Human Oral Mucosa Fibroblasts: Comparison with Dermal Fibroblasts and Induced Pluripotent Stem Cells. Biomed Res Int. 2015;2015:121575. doi: 10.1155/2015/121575. Epub 2015 Aug 3. PMID: 26339586; PMCID: PMC4538314.

9. Phipps RP, Borrello MA, Blieden TM. Fibroblast heterogeneity in the periodontium and other tissues. J Periodontal Res. 1997 Jan;32(1 Pt 2):159-65. doi: 10.1111/j.16000765.1997.tb01398.x. PMID: 9085227.

10. Häkkinen L, Larjava H, Fournier BP. Distinct phenotype and therapeutic potential of gingival fibroblasts. Cytotherapy. 2014 Sep;16(9):1171-86. doi: 10.1016/j.jcyt.2014.04.004. Epub 2014 Jun 13. PMID: 24934304.

11. Mah W, Jiang G, Olver D, Cheung G, Kim B, Larjava H, Häkkinen L. Human gingival fibroblasts display a non-fibrotic phenotype distinct from skin fibroblasts in three- 
dimensional cultures. PLoS One. 2014 Mar 7;9(3):e90715. doi: 10.1371/journal.pone.0090715. PMID: 24608113; PMCID: PMC3946595.

12. Nishioka M, Venkatesan N, Dessalle K, Mogas A, Kyoh S, Lin TY, Nair P, Baglole CJ, Eidelman DH, Ludwig MS, Hamid Q. Fibroblast-epithelial cell interactions drive epithelial-mesenchymal transition differently in cells from normal and COPD patients. Respir Res. 2015 Jun 18;16(1):72. doi: 10.1186/s12931-015-0232-4. PMID: 26081431; PMCID: PMC4473826.

13. Groeger S, Meyle J. Oral Mucosal Epithelial Cells. Front Immunol. 2019 Feb 14;10:208. doi: 10.3389/fimmu.2019.00208. PMID: 30837987; PMCID: PMC6383680.

14. Wang SS, Tang YL, Pang X, Zheng M, Tang YJ, Liang XH. The maintenance of an oral epithelial barrier. Life Sci. 2019 Jun 15;227:129-136. doi: 10.1016/j.lfs.2019.04.029. Epub 2019 Apr 16. PMID: 31002922.

15. Squier CA. The permeability of oral mucosa. Crit Rev Oral Biol Med. 1991;2(1):13-32. doi: 10.1177/10454411910020010301. PMID: 1912142.

16. Li J, Ireland GW, Farthing PM, Thornhill MH. Epidermal and oral keratinocytes are induced to produce RANTES and IL-8 by cytokine stimulation. J Invest Dermatol. 1996 Apr;106(4):661-6. doi: 10.1111/1523-1747.ep12345482. PMID: 8618001.

17. Sharov AA, Schlessinger D, Ko MS. ExAtlas: An interactive online tool for metaanalysis of gene expression data. J Bioinform Comput Biol. 2015 Dec;13(6):1550019. doi: 10.1142/S0219720015500195. Epub 2015 Jun 9. PMID: 26223199; PMCID: PMC5518779.

18. Ashburner M, Ball CA, Blake JA, Botstein D, Butler H, Cherry JM, Davis AP, Dolinski K, Dwight SS, Eppig JT, Harris MA, Hill DP, Issel-Tarver L, Kasarskis A, Lewis S, Matese JC, Richardson JE, Ringwald M, Rubin GM, Sherlock G. Gene ontology: tool for 
the unification of biology. The Gene Ontology Consortium. Nat Genet. 2000 May;25(1):25-9. doi: 10.1038/75556. PMID: 10802651; PMCID: PMC3037419.

19. Gene Ontology Consortium. The Gene Ontology resource: enriching a GOld mine. Nucleic Acids Res. 2021 Jan 8;49(D1):D325-D334. doi: 10.1093/nar/gkaa1113. PMID: 33290552; PMCID: PMC7779012.

20. Kim SY, Volsky DJ. PAGE: parametric analysis of gene set enrichment. BMC Bioinformatics. 2005 Jun 8;6:144. doi: 10.1186/1471-2105-6-144. PMID: 15941488; PMCID: PMC1183189.

21. Zhang Y, De S, Garner JR, Smith K, Wang SA, Becker KG. Systematic analysis, comparison, and integration of disease based human genetic association data and mouse genetic phenotypic information. BMC Med Genomics. 2010 Jan 21;3:1. doi: 10.1186/1755-8794-3-1. PMID: 20092628; PMCID: PMC2822734.

22. Uhlén M, Fagerberg L, Hallström BM, Lindskog C, Oksvold P, Mardinoglu A, Sivertsson Å, Kampf C, Sjöstedt E, Asplund A, Olsson I, Edlund K, Lundberg E, Navani S, Szigyarto CA, Odeberg J, Djureinovic D, Takanen JO, Hober S, Alm T, Edqvist PH, Berling H, Tegel H, Mulder J, Rockberg J, Nilsson P, Schwenk JM, Hamsten M, von Feilitzen K, Forsberg M, Persson L, Johansson F, Zwahlen M, von Heijne G, Nielsen J, Pontén F. Proteomics. Tissue-based map of the human proteome. Science. 2015 Jan 23;347(6220):1260419. doi: 10.1126/science.1260419. PMID: 25613900.

23. Naba A, Pearce OMT, Del Rosario A, Ma D, Ding H, Rajeeve V, Cutillas PR, Balkwill FR, Hynes RO. Characterization of the Extracellular Matrix of Normal and Diseased Tissues Using Proteomics. J Proteome Res. 2017 Aug 4;16(8):3083-3091. doi: 10.1021/acs.jproteome.7b00191. Epub 2017 Jul 19. PMID: 28675934.

24. Zhao M, Liu Y, Zheng C, Qu H. dbEMT 2.0: An updated database for epithelialmesenchymal transition genes with experimentally verified information and precalculated 
regulation information for cancer metastasis. J Genet Genomics. 2019 Dec 20;46(12):595-597. doi: 10.1016/j.jgg.2019.11.010. Epub 2019 Dec 21. PMID: 31941584.

25. Muhl L, Genové G, Leptidis S, Liu J, He L, Mocci G, Sun Y, Gustafsson S, Buyandelger B, Chivukula IV, Segerstolpe Å, Raschperger E, Hansson EM, Björkegren JLM, Peng XR, Vanlandewijck M, Lendahl U, Betsholtz C. Single-cell analysis uncovers fibroblast heterogeneity and criteria for fibroblast and mural cell identification and discrimination. Nat Commun. 2020 Aug 7;11(1):3953. doi: 10.1038/s41467-020-17740-1. Erratum in: Nat Commun. 2020 Sep 3;11(1):4493. PMID: 32769974; PMCID: PMC7414220.

26. Shao X, Taha IN, Clauser KR, Gao YT, Naba A. MatrisomeDB: the ECM-protein knowledge database. Nucleic Acids Res. 2020 Jan 8;48(D1):D1136-D1144. doi: 10.1093/nar/gkz849. PMID: 31586405; PMCID: PMC6943062.

27. Mikesh LM, Aramadhaka LR, Moskaluk C, Zigrino P, Mauch C, Fox JW. Proteomic anatomy of human skin. J Proteomics. 2013 Jun 12;84:190-200. doi: 10.1016/j.jprot.2013.03.019. Epub 2013 Apr 3. PMID: 23563204.

28. Passaro A, Miselli MA, Sanz JM, Dalla Nora E, Morieri ML, Colonna R, Pišot R, Zuliani G. Gene expression regional differences in human subcutaneous adipose tissue. BMC Genomics. 2017 Feb 23;18(1):202. doi: 10.1186/s12864-017-3564-2. PMID: 28231762; PMCID: PMC5324328

29. Myers EM, Bartlett CW, Machiraju R, Bohland JW. An integrative analysis of regional gene expression profiles in the human brain. Methods. 2015 Feb;73:54-70. doi: 10.1016/j.ymeth.2014.12.010. Epub 2014 Dec 15. PMID: 25524419.

30. Xu C, Li Q, Efimova O, He L, Tatsumoto S, Stepanova V, Oishi T, Udono T, Yamaguchi K, Shigenobu S, Kakita A, Nawa H, Khaitovich P, Go Y. Human-specific features of spatial gene expression and regulation in eight brain regions. Genome Res. 2018 
Aug;28(8):1097-1110. doi: 10.1101/gr.231357.117. Epub 2018 Jun 13. PMID: 29898898; PMCID: PMC6071643.

31. Liu Y, Huang H, Sun G, Alwadani S, Semba RD, Lutty GA, Yiu S, Edward DP. Gene Expression Profile of Extracellular Matrix and Adhesion Molecules in the Human Normal Corneal Stroma. Curr Eye Res. 2017 Apr;42(4):520-527. doi: 10.1080/02713683.2016.1200099. Epub 2016 Jul 21. PMID: 27442190; PMCID: PMC6011830.

32. Belleannée C, Thimon V, Sullivan R. Region-specific gene expression in the epididymis. Cell Tissue Res. 2012 Sep;349(3):717-31. doi: 10.1007/s00441-012-1381-0. Epub 2012 Mar 18. PMID: 22427067.

33. Lynch MD, Watt FM. Fibroblast heterogeneity: implications for human disease. J Clin Invest. 2018 Jan 2;128(1):26-35. doi: 10.1172/JCI93555. Epub 2018 Jan 2. PMID: 29293096; PMCID: PMC5749540

34. Aframian DJ, Davidowitz T, Benoliel R. The distribution of oral mucosal pH values in healthy saliva secretors. Oral Dis. 2006 Jul;12(4):420-3. doi: 10.1111/j.16010825.2005.01217.x. PMID: 16792729.

35. Mohd Nor NH, Berahim Z, Azlina A, Mokhtar KI, Kannan TP. Identification and Characterization of Intraoral and Dermal Fibroblasts Revisited. Curr Stem Cell Res Ther. 2017;12(8):675-681. doi: 10.2174/1574888X12666170929124621. PMID: 28969579.

36. Caetano AJ, Yianni V, Volponi A, Booth V, D'Agostino EM, Sharpe P. Defining human mesenchymal and epithelial heterogeneity in response to oral inflammatory disease. Elife. 2021 Jan 4;10:e62810. doi: 10.7554/eLife.62810. PMID: 33393902; PMCID: PMC7781605 
37. Frohwitter G, Buerger H, Korsching E, van Diest PJ, Kleinheinz J, Fillies T. Site-specific gene expression patterns in oral cancer. Head Face Med. 2017 May 10;13(1):6. doi: 10.1186/s13005-017-0138-0. PMID: 28486965; PMCID: PMC5424406.

38. Alhindi NA, Sindi AM, Binmadi NO, Elias WY. A retrospective study of oral and maxillofacial pathology lesions diagnosed at the Faculty of Dentistry, King Abdulaziz University. Clin Cosmet Investig Dent. 2019 Mar 4;11:45-52. doi: 10.2147/CCIDE.S190092. PMID: 30881140; PMCID: PMC6404671;

39. Otali D, Fredenburgh J, Oelschlager DK, Grizzle WE. A standard tissue as a control for histochemical and immunohistochemical staining. Biotech Histochem. 2016 Jul;91(5):309-26. doi: 10.1080/10520295.2016.1179342. Epub 2016 May 5. PMID: 27149658; PMCID: PMC5338041

40. Aran D, Camarda R, Odegaard J, Paik H, Oskotsky B, Krings G, Goga A, Sirota M, Butte AJ. Comprehensive analysis of normal adjacent to tumor transcriptomes. Nat Commun. 2017 Oct 20;8(1):1077. doi: 10.1038/s41467-017-01027-z. PMID: 29057876; PMCID: PMC5651823

41. Bell WC, Sexton KC, Grizzle WE. How to efficiently obtain human tissues to support specific biomedical research projects. Cancer Epidemiol Biomarkers Prev. 2009 Jun;18(6):1676-9. doi: 10.1158/1055-9965.EPI-08-0820. Epub 2009 May 12. PMID: 19435863; PMCID: PMC2694221

42. Nithya S, Joshua E, Ranganathan K, Thavarajah R, Rao UK. Loricrin expression and its implication in oral submucous fibrosis, hyperkeratosis and normal mucosa with association to habits - An immunohistochemical study. J Oral Biol Craniofac Res. 2019 Jul-Sep;9(3):226-231. doi: 10.1016/j.jobcr.2019.05.004. Epub 2019 May 20. PMID: 31193624; PMCID: PMC6536888 
43. Kapila SN, Boaz K, Natarajan S. The post-analytical phase of histopathology practice: Storage, retention and use of human tissue specimens. Int J App Basic Med Res 2016;6:37.

44. Uhlén M, Fagerberg L, Hallström BM, Lindskog C, Oksvold P, Mardinoglu A, Sivertsson Å, Kampf C, Sjöstedt E, Asplund A, Olsson I, Edlund K, Lundberg E, Navani S, Szigyarto CA, Odeberg J, Djureinovic D, Takanen JO, Hober S, Alm T, Edqvist PH, Berling H, Tegel H, Mulder J, Rockberg J, Nilsson P, Schwenk JM, Hamsten M, von Feilitzen K, Forsberg M, Persson L, Johansson F, Zwahlen M, von Heijne G, Nielsen J, Pontén F. Proteomics. Tissue-based map of the human proteome. Science. 2015 Jan 23;347(6220):1260419. doi: 10.1126/science.1260419. PMID: 25613900.

45. Fagerberg L, Hallström BM, Oksvold P, Kampf C, Djureinovic D, Odeberg J, Habuka M, Tahmasebpoor S, Danielsson A, Edlund K, Asplund A, Sjöstedt E, Lundberg E, Szigyarto CA, Skogs M, Takanen JO, Berling H, Tegel H, Mulder J, Nilsson P, Schwenk JM, Lindskog C, Danielsson F, Mardinoglu A, Sivertsson A, von Feilitzen K, Forsberg M, Zwahlen M, Olsson I, Navani S, Huss M, Nielsen J, Ponten F, Uhlén M. Analysis of the human tissue-specific expression by genome-wide integration of transcriptomics and antibody-based proteomics. Mol Cell Proteomics. 2014 Feb;13(2):397-406. doi: 10.1074/mcp.M113.035600. Epub 2013 Dec 5. PMID: 24309898; PMCID: PMC3916642.

46. Frost HR. Analyzing cancer gene expression data through the lens of normal tissuespecificity. PLoS Comput Biol. 2021 Jun 18;17(6):e1009085. doi: 10.1371/journal.pcbi.1009085. PMID: 34143767; PMCID: PMC8244857.

47. El Agha E, Kramann R, Schneider RK, Li X, Seeger W, Humphreys BD, Bellusci S. Mesenchymal Stem Cells in Fibrotic Disease. Cell Stem Cell. 2017 Aug 3;21(2):166-177. doi: 10.1016/j.stem.2017.07.011. PMID: 28777943. 
48. Dohlman AB, Arguijo Mendoza D, Ding S, Gao M, Dressman H, Iliev ID, Lipkin SM, Shen X. The cancer microbiome atlas: a pan-cancer comparative analysis to distinguish tissue-resident microbiota from contaminants. Cell Host Microbe. 2021 Feb 10;29(2):281-298.e5. doi: 10.1016/j.chom.2020.12.001. Epub 2021 Jan 6. PMID: 33382980; PMCID: PMC7878430.

49. Borchmann S. An atlas of the tissue and blood metagenome in cancer reveals novel links between bacteria, viruses and cancer. Microbiome. 2021 Apr 22;9(1):94. doi: 10.1186/s40168-021-01039-4. PMID: 33888160; PMCID: PMC8063312.

Table-1: Matrisome related protein's mRNA over expressed in Human Buccal mucosa $(n=40)$ as compared to Human Gingival mucosa $(n=64)$

\begin{tabular}{|c|c|c|}
\hline Division & Category & Gene Symbol \\
\hline \multirow{3}{*}{$\begin{array}{l}\text { Core } \\
\text { matrisome }\end{array}$} & Collagens & COL6A6; COL10A1 \\
\hline & $\begin{array}{l}\text { ECM } \\
\text { Glycoproteins }\end{array}$ & $\begin{array}{l}\text { PCOLCE2, MFAP5, RSPO3, CILP, RELN, NDNF, DPT, } \\
\text { NTNG1, IGSF10, EMID1, THBS4, IGFBP6, TNC, GLDN, } \\
\text { IBSP, SRPX2, EFEMP1, MFAP4, LAMC1, NTN4, NTN1, } \\
\text { ECM1, MGP, LAMA2, FGL2, FRAS1, ABI3BP, LAMA3, } \\
\text { FNDC1 }\end{array}$ \\
\hline & Proteoglycans & LUM, HSPG2, HAPLN1, OGN \\
\hline \multirow[t]{2}{*}{$\begin{array}{l}\text { Matrisome- } \\
\text { associated }\end{array}$} & ECM Regulators & $\begin{array}{l}\text { ITIH4, F10, PAMR1, CSTB, ST14, PAPPA2, MMP16, ITIH5, } \\
\text { SERPINB8, LOXL4, SERPINB2, OGFOD1, TIMP4, } \\
\text { ADAMTSL4, ADAMTS5, ADAMTS1, TGM1, A2ML1, } \\
\text { PCSK5, SERPINB4, SERPINB7, SERPINB6, KY, CTSV }\end{array}$ \\
\hline & $\begin{array}{l}\text { ECM-affiliated } \\
\text { Proteins }\end{array}$ & $\begin{array}{l}\text { C1QTNF3, SEMA6B, GPC3, SFTA2, C1QTNF7, CLEC3B, } \\
\text { ANXA3, GPC4, ANXA11, CLEC2D, LGALS3, C1QTNF2, }\end{array}$ \\
\hline
\end{tabular}


bioRxiv preprint doi: https://doi.org/10.1101/2021.10.08.463654; this version posted October 9,2021 . The copyright holder for this preprint (which was not certified by peer review) is the author/funder, who has granted bioRxiv a license to display the preprint in perpetuity. It is made available under aCC-BY 4.0 International license.

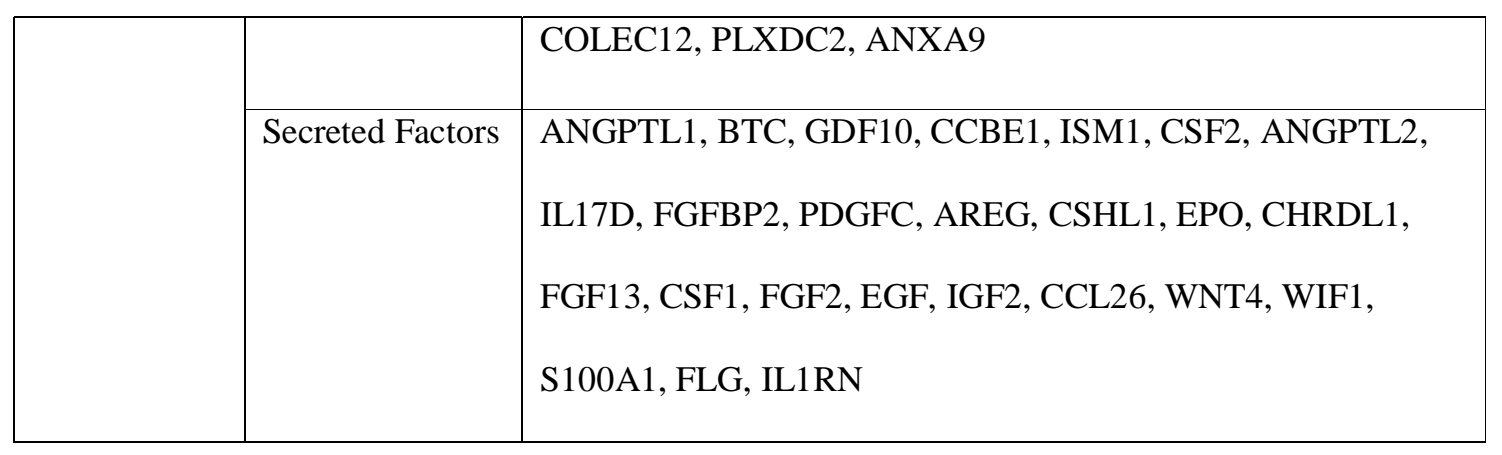


Table-2: Matrisome related protein's mRNA under expressed in Human Buccal mucosa $(n=40)$ as compared to Human Gingival mucosa $(\mathrm{n}=64)$

\begin{tabular}{|c|c|c|}
\hline Division & Category & Gene Symbol \\
\hline \multirow[t]{3}{*}{ Core matrisome } & Collagens & $\begin{array}{l}\text { COL11A1, COL13A1, COL4A5, COL5A2, COL6A3, } \\
\text { COL3A1, COL8A1, COL4A4, COL27A1, COL12A1, } \\
\text { COL4A1, COL4A2 }\end{array}$ \\
\hline & $\begin{array}{l}\text { ECM } \\
\text { Glycoproteins }\end{array}$ & $\begin{array}{l}\text { HMCN2, EDIL3, LAMB3, CTHRC1, CRISPLD1, THBS1, } \\
\text { AGRN, THBS2, SPARC, POSTN, CRISPLD2, NID2, } \\
\text { PCOLCE, SPP1, VWA3A, TNFAIP6 }\end{array}$ \\
\hline & Proteoglycans & ASPN, SRGN \\
\hline \multirow[t]{3}{*}{$\begin{array}{l}\text { Matrisome- } \\
\text { associated }\end{array}$} & ECM Regulators & $\begin{array}{l}\text { CST3, CD109, ADAMTS2, LOX, SERPINB13, MMP11, } \\
\text { ADAMDEC1, TGM7, MMP15, ADAM22, EGLN2, } \\
\text { PRSS12, MMP12, HYAL1, MMP9, MMP19, ADAMTS6, } \\
\text { NGLY1, ADAM28, MASP1, MMP7, EGLN3, MMP13, } \\
\text { SERPINA1, TIMP2, LOXL2, BMP1, ADAM12, MMP10, } \\
\text { MMP1, SERPINB5, MMP3, FAM20A, PCSK6, FAM20C, } \\
\text { SERPINE1, PI3 }\end{array}$ \\
\hline & $\begin{array}{l}\text { ECM-affiliated } \\
\text { Proteins }\end{array}$ & ANXA2, CLEC4E, CLEC7A, C1QTNF1, SEMA5B \\
\hline & Secreted Factors & $\begin{array}{l}\text { IL22, MEGF9, WNT5A, TNFSF10, CXCL13, RPTN, } \\
\text { CXCL1, S100A7, INHBA, CBLN2, CCL28, CXCL8, } \\
\text { CXCL2, CCL20, IL19, CCL4, CXCL6, CCL3, CXCL3, } \\
\text { CXCL5, BMP6, IL24, FRZB, S100A7A, CCL2, IL6, FLG2, } \\
\text { CCL19, SFRP1, CXCL10 }\end{array}$ \\
\hline
\end{tabular}


Table-3: Expression of fibroblastic markers in the Human Buccal mucosa $(n=40)$ as compared to Human Gingival mucosa $(n=64)$

\begin{tabular}{|c|c|c|c|c|c|c|c|c|c|c|c|}
\hline $\begin{array}{l}\text { Gene } \\
\text { Symbol }\end{array}$ & $\begin{array}{l}\text { Average } \\
\text { Intensity }\end{array}$ & $\begin{array}{l}\text { Human buccal } \\
\text { Mucosa }(n=40)\end{array}$ & $\begin{array}{c}\text { Human Gingival } \\
\text { mucosa }(n=64)\end{array}$ & $\begin{array}{l}\text { Variance } \\
\text { (Factor) }\end{array}$ & $\begin{array}{l}\text { Variance } \\
\text { (Err) }\end{array}$ & $\begin{array}{l}\text { Smooth } \\
\text { Variance } \\
\text { (Err) }\end{array}$ & $\begin{array}{l}\text { Final } \\
\text { MSE }\end{array}$ & $\begin{array}{l}\text { F- } \\
\text { statistics }\end{array}$ & $\mathbf{P}$ & FDR & rank \\
\hline MFAP5 & 1.7253 & 2.2919 & 1.1587 & 31.61427 & 0.02545 & 0.01496 & 0.02545 & 1242.374 & 0 & 0 & 698 \\
\hline ADAMTS2 & 2.0129 & 1.5902 & 2.4356 & 17.59442 & 0.02881 & 0.01644 & 0.02881 & 610.774 & 0 & 0 & 1325 \\
\hline DPT & 2.3227 & 2.7092 & 1.9362 & 14.70734 & 0.03152 & 0.01554 & 0.03152 & 466.55 & 0 & 0 & 1686 \\
\hline S100A16 & 3.9037 & 3.9999 & 3.8075 & 0.91167 & 0.00266 & 0.00906 & 0.00266 & 343.166 & 0 & 0 & 2229 \\
\hline IGFBP6 & 3.1453 & 3.4865 & 2.804 & 11.46702 & 0.03519 & 0.01175 & 0.03519 & 325.84 & 0 & 0 & 2319 \\
\hline NAV1 & 2.0801 & 1.864 & 2.2962 & 4.59665 & 0.01755 & 0.01614 & 0.01755 & 261.848 & 0 & 0 & 2868 \\
\hline SCARA5 & 2.4022 & 2.7477 & 2.0568 & 11.75022 & 0.063 & 0.01511 & 0.063 & 186.526 & 0 & 0 & 3777 \\
\hline RNASE4 & 2.2312 & 2.3937 & 2.0686 & 2.60063 & 0.0142 & 0.01681 & 0.0142 & 183.19 & 0 & 0 & 3844 \\
\hline GSN & 2.4363 & 2.6528 & 2.2198 & 4.61547 & 0.02754 & 0.01483 & 0.02754 & 167.571 & 0 & 0 & 4160 \\
\hline MEDAG & 1.9843 & 2.1431 & 1.8255 & 2.48321 & 0.01925 & 0.01573 & 0.01925 & 128.986 & 0 & 0 & 5100 \\
\hline PI16 & 1.9328 & 2.0479 & 1.8177 & 1.30357 & 0.01135 & 0.01683 & 0.01135 & 114.884 & 0 & 0 & 5579 \\
\hline HTRA3 & 1.7017 & 1.7924 & 1.611 & 0.8096 & 0.00849 & 0.01516 & 0.00849 & 95.385 & 0 & 0 & 6319 \\
\hline
\end{tabular}




\begin{tabular}{|c|c|c|c|c|c|c|c|c|c|c|c|}
\hline$\overline{\mathrm{DCN}}$ & 3.4857 & 3.3553 & 3.6161 & 1.67483 & 0.02221 & 0.0101 & 0.02221 & 75.395 & 0 & 0 & 7334 \\
\hline CD34 & 2.0667 & 2.1721 & 1.9614 & 1.09282 & 0.01477 & 0.01654 & 0.01477 & 73.979 & 0 & 0 & 7428 \\
\hline $\mathrm{C} 3$ & 2.5953 & 2.768 & 2.4226 & 2.93593 & 0.04736 & 0.01433 & 0.04736 & 61.986 & 0 & 0 & 8222 \\
\hline FBLN1 & 2.5693 & 2.7181 & 2.4204 & 2.18212 & 0.03812 & 0.01379 & 0.03812 & 57.241 & 0 & 0 & 8647 \\
\hline LSP1 & 2.2338 & 2.3348 & 2.1328 & 1.00462 & 0.02097 & 0.0167 & 0.02097 & 47.897 & 0 & 0 & 9447 \\
\hline FBLN2 & 2.2682 & 2.1947 & 2.3418 & 0.53318 & 0.02114 & 0.01631 & 0.02114 & 25.218 & 0 & 0 & 12322 \\
\hline COL1A2 & 2.9908 & 2.9026 & 3.079 & 0.7663 & 0.0378 & 0.01189 & 0.0378 & 20.271 & 0.00002 & 0.00003 & 13194 \\
\hline LOXL1 & 2.176 & 2.1031 & 2.2489 & 0.52319 & 0.02654 & 0.01643 & 0.02654 & 19.713 & 0.00002 & 0.00004 & 13309 \\
\hline MMP2 & 2.7886 & 2.6945 & 2.8827 & 0.87235 & 0.04547 & 0.01264 & 0.04547 & 19.183 & 0.00003 & 0.00005 & 13405 \\
\hline CCDC80 & 2.1613 & 2.2333 & 2.0892 & 0.51087 & 0.04333 & 0.01643 & 0.04333 & 11.789 & 0.00086 & 0.0013 & 15136 \\
\hline OLFML3 & 2.3478 & 2.408 & 2.2875 & 0.35735 & 0.03091 & 0.01531 & 0.03091 & 11.562 & 0.00096 & 0.00144 & 15189 \\
\hline BICC1 & 1.907 & 1.8595 & 1.9544 & 0.2214 & 0.02466 & 0.01695 & 0.02466 & 8.979 & 0.00343 & 0.00486 & 16030 \\
\hline PDGFRA & 2.8541 & 2.8137 & 2.8945 & 0.16057 & 0.02236 & 0.01219 & 0.02236 & 7.182 & 0.00859 & 0.01168 & 16717 \\
\hline GFPT2 & 1.7615 & 1.738 & 1.785 & 0.05438 & 0.01748 & 0.0152 & 0.01748 & 3.111 & 0.08077 & 0.0981 & 18721 \\
\hline ENTPD2 & 1.5199 & 1.5357 & 1.5041 & 0.02465 & 0.00983 & 0.01516 & 0.00983 & 2.507 & 0.11645 & 0.13831 & 19143 \\
\hline SERPINF1 & 2.9651 & 2.9421 & 2.988 & 0.05187 & 0.02608 & 0.01205 & 0.02608 & 1.989 & 0.16153 & 0.18836 & 19499 \\
\hline MGST1 & 2.4282 & 2.3839 & 2.4724 & 0.19169 & 0.10107 & 0.01527 & 0.10107 & 1.897 & 0.17151 & 0.19927 & 19567 \\
\hline
\end{tabular}




\begin{tabular}{|l|l|l|l|l|l|l|l|l|l|l|l|}
\hline S100A10 & 2.6527 & 2.6331 & 2.6723 & 0.03777 & 0.0334 & 0.01415 & 0.0334 & 1.131 & 0.29006 & 0.32545 & 20265 \\
\hline UGDH & 2.5123 & 2.501 & 2.5235 & 0.01247 & 0.01519 & 0.01382 & 0.01519 & 0.821 & 1 & 1 & 20631 \\
\hline
\end{tabular}




\section{LEGENDS:}

FIGURE 1: Relationship between the Human Buccal Mucosa and Human Gingival Mucosal Samples

A. Tissue B. Genes in Principal Component Analysis

FIGURE-2: Different components of the Principal Component Analysis of various samples studied.

FIGURE-3: Scatter-plot showing the differentially expressed genes between Human Buccal Mucosal and Human Gingival Mucosal Samples.

FIGURE-4: Overall differences between various gene expressions of Human Buccal Mucosa and Human Gingival Mucosal Samples. 


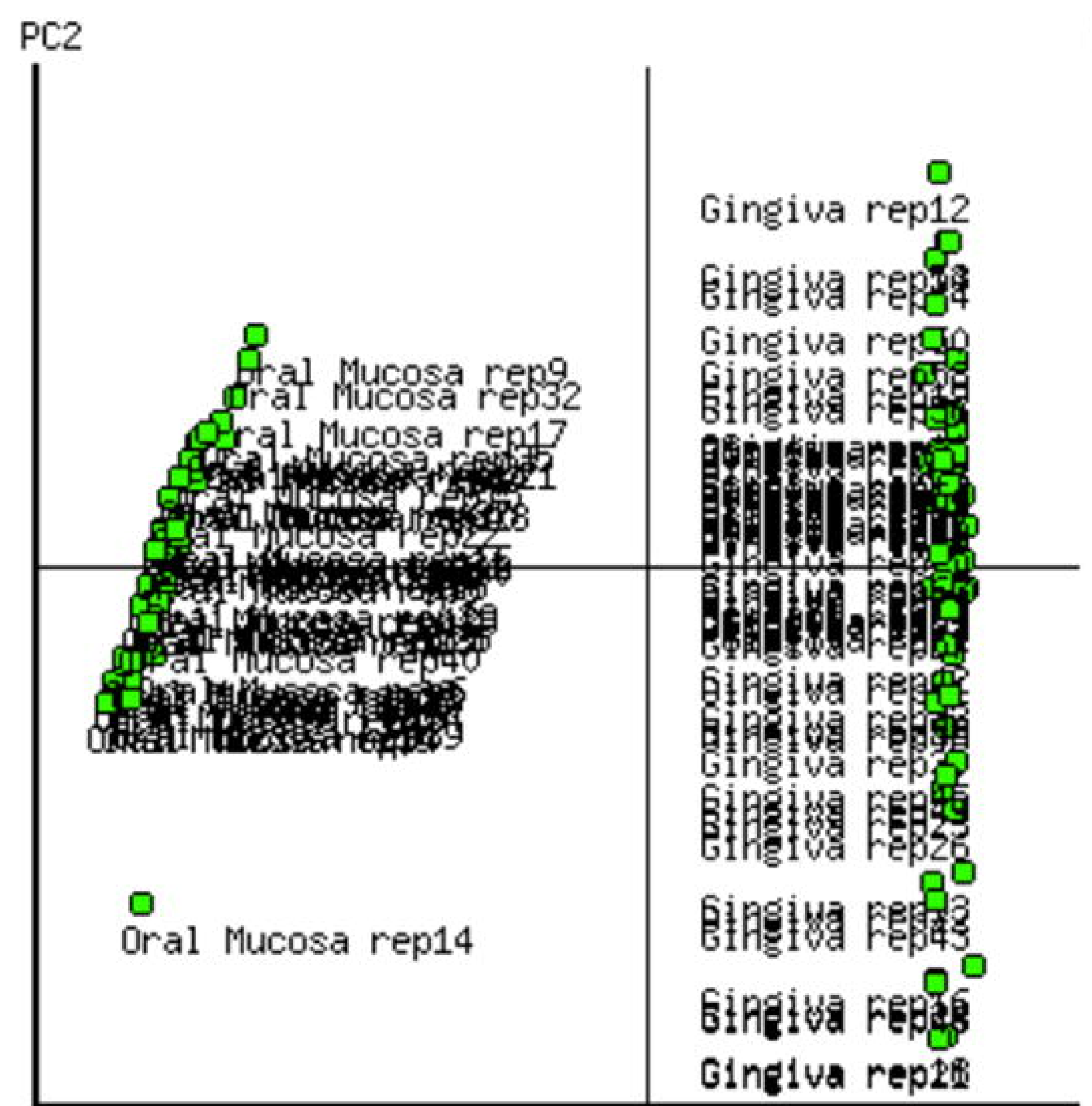

PC1

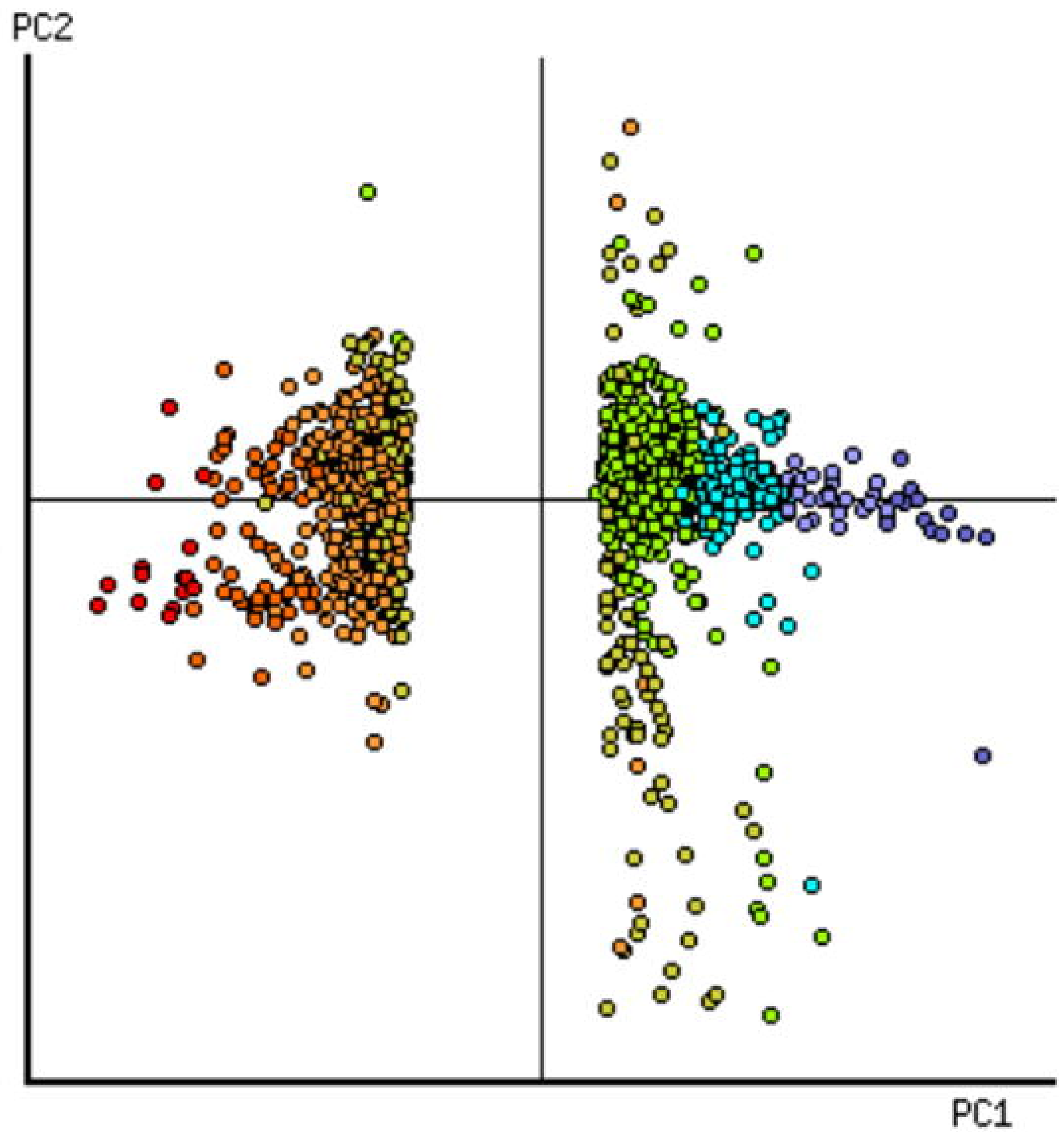




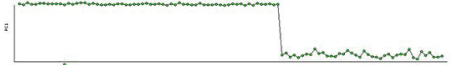

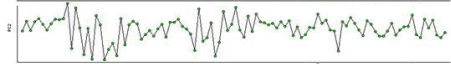

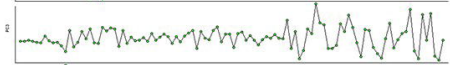

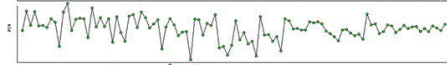

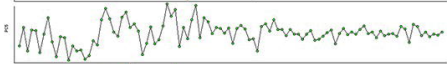

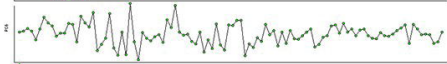

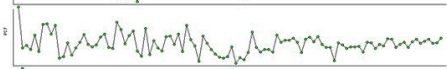

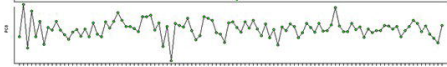

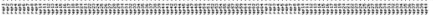

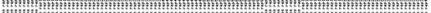

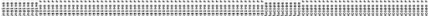

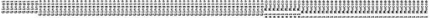

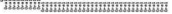




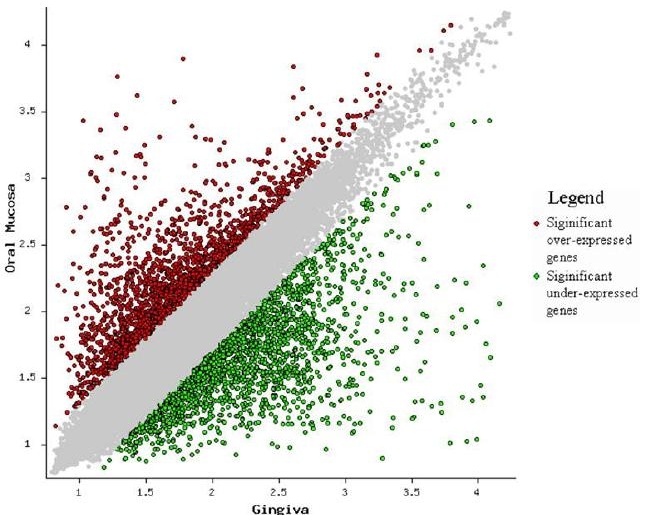




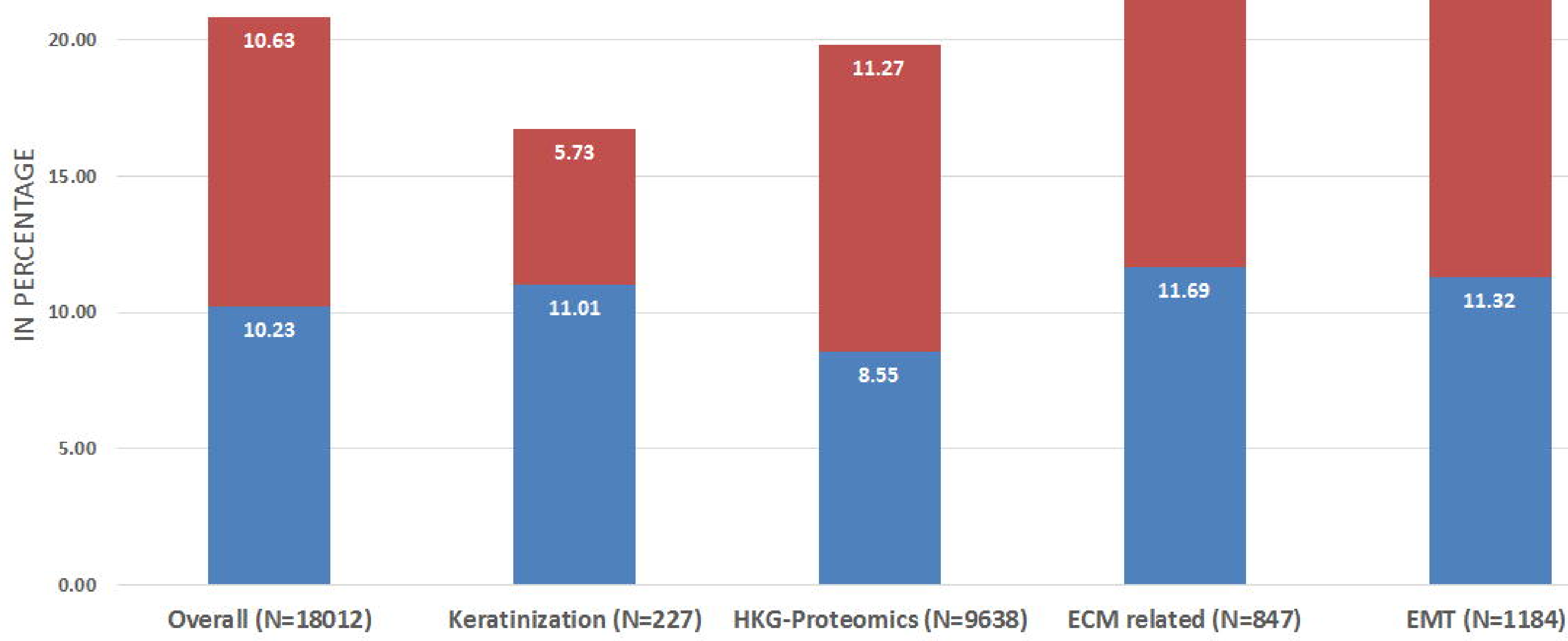

